\title{
Variations in Weed Population Densities, Rate of Change and COMmunity Diversity IN RR-SOYBEANS AND RR-MAIZE STRIP CROPS UNDER Two HeRbicide STRATEgIES ${ }^{1}$
}

\author{
Ação de Herbicidas sobre as Plantas Daninhas na Soja e Milho RR em Plantio Consorciado
}

\author{
LEGUIZAMÓN, E.S. ${ }^{2}$, VERDELLI, D.M. ${ }^{3}$, and ACCIARESI, H. ${ }^{4}$
}

\begin{abstract}
Concerns about the sustainability of large-scale, direct-drilled RR-soybeans (Glycine max), and RR-maize (Zea mays) under monoculture in central Argentina are growing steadily. An experiment was conducted during three consecutive years to determine the effects of crops and systems (monocultures and strips) and herbicide strategy on weed density, population rate of change (1), b community diversity ( $\left.\mathrm{H}^{-}\right)$, crop yields and Land Equivalent Ratio (LER). Not only crops but also crop systems differentially influenced weed densities along their growth and development. For crop harvests, weed densities increased in both maize crop systems as compared to in the one for soybeans, but the lowest increase occurred in soybean strips. Differences were leveled by both herbicide strategies, which achieved $73 \%$ efficacy during the critical periods in both crops. 1 of annual monocotyledonous increased, thus shifting the weed community composition. Species richness and $\mathrm{H}^{`}$ were not affected by crop systems, but both herbicide strategies, particularly POST, either in soybeans in monoculture or in maize strips, significantly enhanced $\mathrm{H}^{\circ}$. Crop yields significantly increased in the maizestrip system with POST (Year 1) or PRE (Years 2 and 3) strategies, thus increasing LER above 1. Herbicide Environmental Load treatments fall within very low or low field use rating.
\end{abstract}

Keywords: strip-intercropping, trajectory, weed shifts, herbicide environmental load, environmental impact quotient.

RESUMO - A preocupação com a sustentabilidade do plantio direto da monocultura e do consórcio de soja e milho RR plantados em grande escala na região central da Argentina cresce continuamente. Durante três anos consecutivos, foram determinados os efeitos das culturas de soja e de milho RR, dos sistemas de plantio (monoculturas e consorciado), e a ação de herbicidas sobre a densidade de plantas daninhas, a taxa de mudança da população, a diversidade da comunidade, as safras e a razão de área equivalente. Não apenas as culturas, mas também os sistemas de plantio, influenciaram as densidades de plantas daninhas ao longo de seu crescimento e desenvolvimento. Durante as safras, a densidade de plantas daninhas aumentou em ambos os sistemas de plantio para milho, em comparação com a soja; o menor aumento ocorreu no plantio consorciado da soja. As diferenças foram semelhantes devido à ação dos herbicidas, os quais alcançaram 73\% de eficácia durante os periodos críticos nas duas culturas. A taxa de mudança da população de monocotiledôneas anuais aumentou, o que deslocou a composição da comunidade de plantas daninhas. Os sistemas de plantio não alteraram a diversidade de espécies, porém a aplicação de ambos os herbicidas, particularmente em pós-emergência, na soja em monocultura ou no milho em consórcio melhorou a diversidade. A colheita aumentou no sistema de milho em consórcio com controle em pós (ano 1) ou em pré (anos 2 e 3), aumentando assim a razão de área equivalente para valor acima de 1. Os tratamentos com herbicidas-quanto a impactos ambientais - são classificados como muito baixo ou baixo, em relação à utilização em campo.

Palavras-chave: consórcio, manejo de plantas daninhas, herbicidas de impacto ambiental, quociente de impacto ambiental.

Recebido para publicação em 22.1.2012 e aprovado em 25.4.2012.

2 Engoํ-Agro ${ }^{-}$, Dr., Pesquisador da CONICET, Professor da Faculdade de Ciências Agrárias da Universidade Nacional de Rosário, Rosário-Argentina, <laupamar@arnet.com.ar>; ${ }^{3}$ Engo-Agrọ., Tecnólogo em Produção de Grãos < dmverdelli³@nodosud.com.ar>; ${ }^{4}$ Eng ${ }^{-}$-Agr ${ }^{\circ}$., Dr, Pesquisador da CIC, Professor da Facultade de Ciencias Agrarias e Florestaes da Universidade Nacional de La Plata. La Plata. Argentina, <acciaresi@agro.unlp.edu.ar>. 


\section{INTRODUCTION}

Weeds in agricultural crops have always been considered detrimental because they interfere with the growth, development and yield of crop species, accounting for a large loss in production. Competition from weeds can be potentially lessened by growing two or more crop species together, a practice known as intercropping and defined as the growth of two or more crops in proximity in the same field during the same growing season with the aim of promoting a positive interaction between them. One key point to maximize yields in this crop system is to select crops and/or seeding dates which allow theminimization or the eventual avoidance of an overlap of the critical periods (Sarandon \& Chamorro, 2004). Because yield is a consequence of crop biomass accumulation, the concept that intercropping can create higher crop biomass with the same level of growth resources, which may be assessed by the calculation of Land Equivalent Ratio (LER, (Mead \& Willey, 1980) has made this production system increasingly studied (Acciaresi \& Sarandón, 2001). Because strip intercropping involves more species, it resembles a natural ecosystem, and the spatial diversity can lead to increased total yield. Intercrops may be more effective than sole crops in capturing resources from weeds, thus resulting in reduced weed growth and greater crop yields; as a result, the use of herbicides may be reduced (Liebman \& Dyck, 1993).

Extensive crops such as wheat and maize have been cultivated under yearly monocultures for more than a century in Argentina. RR-soybean, introduced in 1997, is currently sown in almost $99 \%$ of an area over $16 \mathrm{M}$ has. Although RR-maize cultivars have been introduced more recently, it is envisaged that the trend will be similar, as both crops are the main components of monocultured crop sequences sown under direct drilling, a management technique applied in most of the extensive non-irrigated agroecosystems in Argentina (Leguizamón, 2001). The direct drilling system is totally dependent on herbicides for weed control and the trend of actual weed management strategies within the crops is to the decrease the use of herbicides with residual activity. There are also concerns about the intensification of monocultured RR crops as regards weed community shifts (Vitta et al., 2004; Culpepper, 2006), herbicides environmental load (Brookes \& Barfoot, 2008), weed glyphosate resistant species (Owen \& Zelaya, 2005) and sustainability (Powles, 2008). Considering the scenario describedabove, we designed a threeyear experiment to investigate whether or not RR maize/soybeans strip-intercropping system and herbicide strategy: a) modified the density of weed populations, $b$ ) altered its rate of change $(\lambda)$ or trajectory along the three-year sequence, and c) influenced the community $\beta$ diversity $\left(H^{\prime}\right)$. The experiment also tested which crop system and herbicide strategy enhanced yields, thus increasing LER, combined to the lowest environmental load.

\section{MATERIALS AND METHODS}

Three-year experiments were conducted in Monte Buey (Córdoba), Argentina (32 $94^{\circ} 41^{\prime \prime S}$ - 62 $\left.{ }^{\circ} 58^{\prime} 97^{\prime \prime} \mathrm{W}\right)$, in a highly productive soil (Typical Argiudol) cultivated under direct drilling since 1996, on a glyphosate-treated winter fallow, without emerged weeds. Two RR crops were tested, soybeans and maize, cv. DM 4800, maturity group V; intermediate cycle single DK 684 hybrid, respectively. Two crop systems were considered: monoculture and strips. In the strips, one crop was planted in the central four rows and the other in the four rows at each side. In each crop and crop system, two herbicide strategies were used: preemergence (PRE) and postemergence (POST). The herbicides sprayed in PRE were imazethapyr (SL 10\%, $100 \mathrm{~g}$ a.i. ha ${ }^{-1}$ ) in soybeans and atrazine (WG 80\%, 2000 g a.i. ha $^{-1}$ ) in maize. The herbicide sprayed in POST was glyphosate (SWG 74.7\%, $960 \mathrm{~g}$ a.i. ha-1) applied at $\mathrm{V}_{6}$ and $\mathrm{V}_{8}$ growth stages (maize and soybeans, respectively). Non-herbicide, control plots were also included (TEST), thus resulting in twelve treatments (Table 1). Treatments were placed under a complete randomized block design with four replicates, in the same experimental site along three growing seasons (2006-7, Y1; 2007-08, Y2 and 2008-09, Y3). Experimental units consisted of 12 rows, $8 \mathrm{~m}$ length $\times 6.3 \mathrm{~m}$ width plots, with an inter-row spacing of $0.52 \mathrm{~m}$ and a density of 8 and 24 plants $\mathrm{m}^{2}$ in maize and in soybeans, respectively. The location of each treatment in a subsequent year was made by taking into 
Table 1 - Treatment codes of crop systems (monocultures and strip-intercropping) of soybeans and maize under two herbicide strategies: preemergence (PRE) and postemergence (POST). TEST, non herbicide or control treatments, also included

\begin{tabular}{|c|c|c|c|}
\hline Treatment $\mathrm{n}^{\mathrm{o}}$ & & Herbicide treatment & Treat codes \\
\hline 1 & \multirow{3}{*}{ SOYBEAN MONOCULTURE } & TEST & SOYMC TEST \\
\hline 2 & & IMAZETAPHYR & SOYMC+IMZ \\
\hline 3 & & GLYPHOSATE & SOYMC+GLF \\
\hline 4 & \multirow{3}{*}{ SOYBEAN STRIP SIDED BY MAIZE } & TEST & SOYSTP TEST \\
\hline 5 & & IMAZETAPHYR / ATRAZINE & SOYSTP+IMZ \\
\hline 6 & & GLYPHOSATE / GLYPHOSATE & SOYSTP+GLF \\
\hline 7 & \multirow{3}{*}{ MAIZE MONOCULTURE } & TEST & MZEMC TEST \\
\hline 8 & & ATRAZINE & MZEMC+ATZ \\
\hline 9 & & GLYPHOSATE & MZEMC+GLF \\
\hline 10 & \multirow{3}{*}{ MAIZE STRIP SIDED BY SOYBEANS } & TEST & MZESTP TEST \\
\hline 11 & & ATRAZINE / IMAZETAPHYR & MZESTP+ATZ \\
\hline 12 & & GLYPHOSATE / GLYPHOSATE & MZESTP+GLF \\
\hline
\end{tabular}

consideration the location of previous year crop in order to maintain crop sequence (e.g. Treatments $\mathrm{N}^{\circ} 1-7$ and 1 were placed in the same plot in Years 1, 2 and 3 respectively). Crop system and herbicide strategy were also maintained along the three subsequent years.

Nitrogen-UAN (N-P-K. 32-0-0, 200 kg N ha-1), and phosphorus-mono ammonium phosphate (N-P-K. 12-52-0, $24 \mathrm{~kg} \mathrm{~N} \mathrm{ha}^{-1}$ and $104 \mathrm{~kg} \mathrm{P} \mathrm{ha}^{-1}$ ) plus $\mathrm{SO}_{4} \mathrm{Ca}, 350 \mathrm{~kg} \mathrm{ha}^{-1}$, were applied every year, a week before the planting date. Insect management was carried out by using thresholds and spraying recommended insecticides. The hand-weeding method had to be used because of an unexpected increase in volunteer RR maize plants during $\mathrm{Y} 3$ at stages V12-R1 for soybeans and V8-V13 for maize.

\section{Measurements and variables}

Seeding and harvesting crop dates, Growing Degree Days (GDD) and its corresponding phenology stages (Fehr \& Caviness, 1977; Ritchie \& Hanway, 1982) at weed sampling times are shown in Table 2 . At harvest time, crop plants selected within the central two rows located along the central 3 $\mathrm{m}$. of every single row were hand cut off, and yield was determined after threshing them by using an experimental plot grain thresher. All grain weights were corrected to the standard $13.5 \%$ grain humidity. where: Y. Maize (strip) is the maize yield in the strip corn sided by soybeans and Y. Soybean (strip) is the soybean yield in the soybean strip. Y. Maize (Mono) and Y. Soybeans (Mono) are yields in monoculture respectively.

Weed seedlings were counted in four $0.20 \mathrm{~m}^{2}$ quadrats, randomly placed in the central inter-row of each plot at five selected times $\left(\mathrm{S}_{1} \ldots \mathrm{Sn}\right)$, each year (Table 2$)$. Nine species were recorded: Cyperus rotundus, Digitaria sanguinalis, Echinochloa colona, Eleusine indica, Sorghum halepense, Amaranthus quitensis, Datura ferox, Chenopodium album and Portulaca oleracea.

Herbicide efficacy was calculated by taking into consideration the three-year average weed density in PRE or POST in each crop or crop system as compared to that in TEST, at sample times S2 and S5, as at S2 we captured the efficacy of the herbicides strategies within the critical period of weed competition (Eyherabide \& Cendoya, 2002; Hall et al., 1992; Bedmar et al., 1999) while at S5 comparisons may give indicate the degree of success of the each herbicide strategy along the whole crop cycle.

The rate of change of weed densities $(\lambda)$ or its trajectory (Cousens \& Mortimer, 1995) along

LER was calculated as:

$$
L E R=\frac{Y . \text { Maize }(\text { Strip })+Y . \text { Soyabeans }(\text { Strip })}{Y . \text { Maize }(\text { Mono })+Y . \text { Soyabeans }(\text { Mono })}
$$


Table 2 - Crops sowing dates, Growing Degree Days (GDD) corresponding to their phenological stages at five sampling dates $(\mathrm{S} 1, \ldots \mathrm{Sn})$ of weeds and harvest dates for maize and soybeans, respectively, in Years 1, 2 and 3

\begin{tabular}{|c|c|c|c|c|c|c|c|c|c|c|c|c|c|c|}
\hline \multirow{3}{*}{$\stackrel{\overline{\nexists ् य}}{\grave{\nu}}$} & \multirow{2}{*}{\multicolumn{2}{|c|}{$\begin{array}{c}\text { Crops sowing } \\
\text { dates }\end{array}$}} & \multicolumn{10}{|c|}{ GDD and corresponding crop phenological stages at weed sampling } & \multirow{2}{*}{\multicolumn{2}{|c|}{ Harvest dates }} \\
\hline & & & \multicolumn{2}{|c|}{$\mathrm{S} 1$} & \multicolumn{2}{|c|}{$\mathrm{S} 2$} & \multicolumn{2}{|c|}{$\mathrm{S} 3$} & \multicolumn{2}{|c|}{$\mathrm{S} 4$} & \multicolumn{2}{|c|}{ S5 } & & \\
\hline & 胥 & 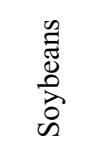 & 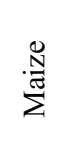 & 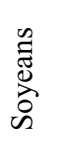 & $\sum_{\substack{\tilde{N}\\
}}^{0}$ & 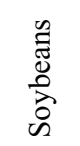 & 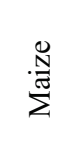 & 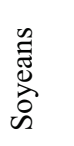 & $\stackrel{\stackrel{N}{N}}{\sum_{\Sigma}^{*}}$ & 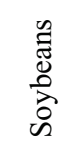 & 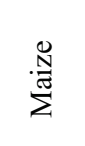 & 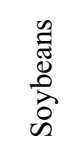 & 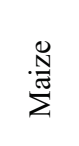 & 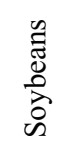 \\
\hline 1 & $12 / 10$ & $10 / 11$ & $\begin{array}{l}520 \\
\text { V4 }\end{array}$ & $\begin{array}{l}525 \\
\text { V5 }\end{array}$ & $\begin{array}{l}778 \\
\text { V8 }\end{array}$ & $\begin{array}{l}696 \\
V 12\end{array}$ & $\begin{array}{l}962 \\
\text { V13 }\end{array}$ & $\begin{array}{l}868 \\
\mathrm{R} 1\end{array}$ & $\begin{array}{c}1067 \\
\mathrm{Vt}\end{array}$ & $\begin{array}{c}1187 \\
\text { R3 }\end{array}$ & $\begin{array}{c}1289 \\
\text { R5 }\end{array}$ & $\begin{array}{l}1325 \\
\mathrm{R} 5.5\end{array}$ & $15 / 3$ & $4 / 4$ \\
\hline 2 & $12 / 10$ & $16 / 11$ & $\begin{array}{c}480 \\
\text { V4 }\end{array}$ & $\begin{array}{l}490 \\
\text { V5 }\end{array}$ & $\begin{array}{c}690 \\
\text { V8 }\end{array}$ & $\begin{array}{l}705 \\
\text { V12 }\end{array}$ & $\begin{array}{l}1001 \\
\text { V13 }\end{array}$ & $\begin{array}{c}904 \\
\mathrm{R} 1\end{array}$ & $\begin{array}{c}1087 \\
\mathrm{Vt}\end{array}$ & $\begin{array}{c}1176 \\
\text { R3 }\end{array}$ & $\begin{array}{c}1290 \\
\text { R5 }\end{array}$ & $\begin{array}{l}1354 \\
\text { R5.5 }\end{array}$ & $7 / 3$ & $2 / 4$ \\
\hline 3 & $14 / 10$ & $09 / 11$ & $\begin{array}{l}525 \\
\text { V4 }\end{array}$ & $\begin{array}{l}530 \\
\text { V5 }\end{array}$ & $\begin{array}{l}720 \\
\text { V8 }\end{array}$ & $\begin{array}{l}698 \\
\text { V12 }\end{array}$ & $\begin{array}{l}980 \\
\text { V13 }\end{array}$ & $\begin{array}{c}893 \\
\mathrm{R} 1\end{array}$ & $\begin{array}{c}1109 \\
\text { Vt }\end{array}$ & $\begin{array}{c}1190 \\
\text { R3 }\end{array}$ & $\begin{array}{c}1302 \\
\text { R5 }\end{array}$ & $\begin{array}{l}1385 \\
\text { R5.5 }\end{array}$ & $22 / 3$ & $7 / 4$ \\
\hline
\end{tabular}

the three-year sequence was calculated for each species or grouped into annual (mono and dycotiledonous) or perennials in each treatment by dividing the densities at S5-Y3 by the densities at S5-Y1.

Weed communities Shannon-Wiener Index of $\beta$ Diversity $\left(H^{-}\right)$at crops harvests (S5-Y3), were calculated as shown below:

$$
\mathrm{H}^{\prime}=-\mathrm{p}_{\mathrm{i}} \cdot \Sigma \log _{10} \mathrm{p}_{\mathrm{i}}
$$

where: $p_{i}$ is the proportion of each species inthe sample.

Herbicide environmental load (HEL) was calculated in each treatment following Kovach et al., 1992 as shown below:

$\mathrm{HEL}=$ Herbicide rate $\left(\mathrm{kg}\right.$ a.i. $\left.\mathrm{ha}^{-1}\right) \mathrm{x}$ Environmental Index Quotient-EIQ (Kovach et al., 1992) x crop surface $\left(\mathrm{m}^{-2}\right)$ in the plot.

Temperature and rainfall data were recorded with an automatic weather station located at $1.500 \mathrm{~m}$ from the experimental site.

\section{Statystical analysis}

After testing for the assumptions, analyses of variance were carried out to determine the effects of the treatments on weed density (transformed to weed density ${ }^{0.5}$ ), herbicide efficacy, population change rate $(\lambda)$, community diversity $(H)$, crop yield, and LER. For those variables sequentially measured along crop cycles (weed density), a second-order interaction between treatments, year and sampling date were calculated. Means were compared by using Fisher's Protected LSD test at $p<0.05$. The statistical package Statgraphics-Plus 5.1 was used.

\section{RESULTS AND DISCUSSION}

It is important to remember the frame of the experiment: first, since depending on the crop architecture and height and interrow width, the influence of the border to inner rows, varies (Lesoing \& Francis, 1999), plot width was determined by considering the results of experiments made in the same site, which demonstrated that the influence of the border row did not extend beyond the adjacent, inner, fourth row. Thus, we decided to use a width of twelve rows in monocultures, and four central rows of a crop sided by four rows of the companion crop at each side in the case of the strips.

Secondly, since there is a consistent body of agronomic knowledge supporting the benefits of rotating grasses with legume crops, a soybeans-maize-soybeans crops sequence (or vice versa) was maintained along the threeyear experiment in all treatments. Thus the term "monoculture" is used in this paper to distinguish it from a "strip-crop", only on a yearly basis. 


\section{Weather}

Air temperatures had a similar pattern in the three years (Figure 1A) showing a steadyincrease pattern from mid-September to early January. Although total rainfalls were within the average for the region, Y2 was the driest season (total rainfall $540 \mathrm{~mm}$ ) as compared to Y1 (967 mm) and Y3 (716 mm) (Figure 1B).

\section{Averaged three-year weed densities}

Significant interactions were found in the weed densities among sampling times, years and treatments (Table 3). Thus, an ANOVA was performed for each sampling data set, indicating the lack of interaction among years (not shown). Thus, the results show the
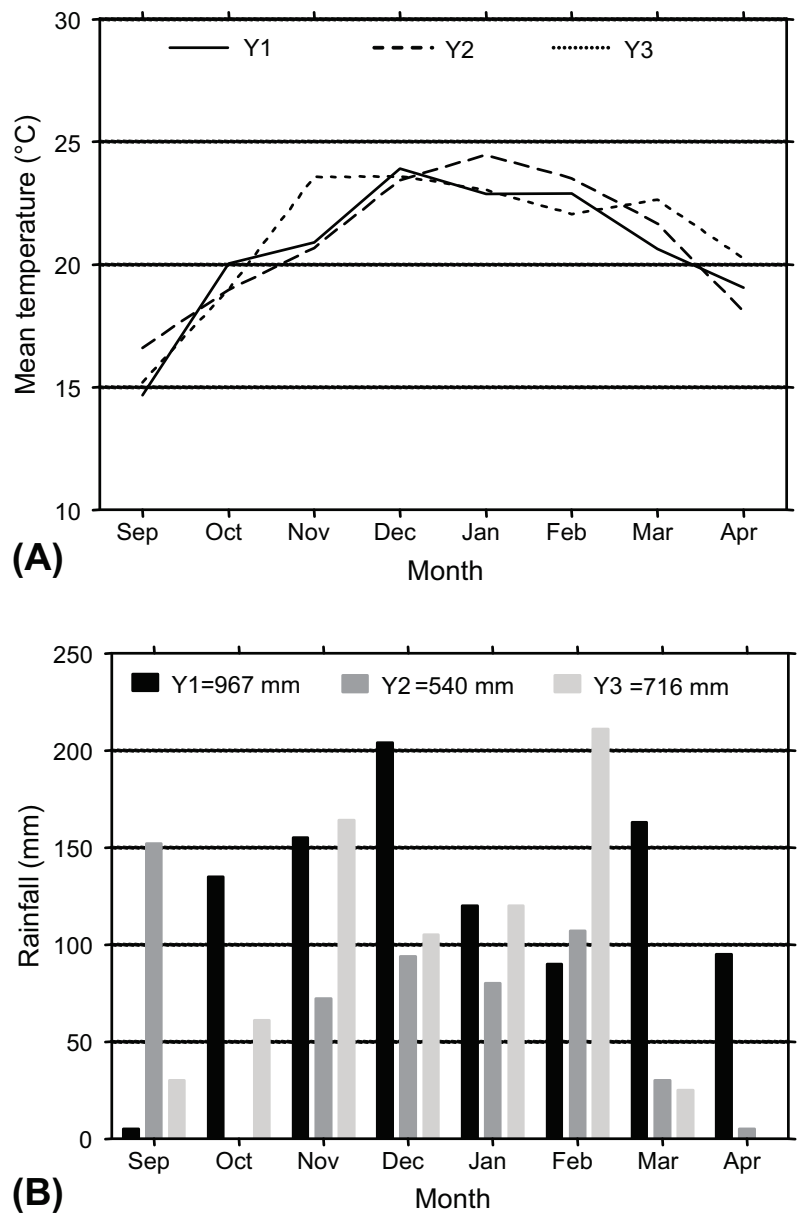

Figure 1 - (A) Mean air temperature in Y1, Y2 and Y3. (B) Rainfall in Y1, Y2 and Y3. averaged weed density in each one of the following times and corresponding crop stages for maize and soybeans, respectively: S1 (V4/ V5), S2 (V8/V12), S3 (V13/R1), S4 (Vt/R3) and S5 (R5.5/R5.5) (Table 4).

Crops and crop systems had significant influence on total weed density in TEST. Weed densities recorded in both soybeans crop systems and maize strips were significantly lower than those for maize in monoculture at S1 and S2 (327 and 411 plants $\mathrm{m}^{-2}$, respectively). Although differences were leveled as crop growth progressed (S3), the same situation occurred for S4. By harvest time (S5), the lowest weed density was recorded in soybeans strips (294 plants $\left.\mathrm{m}^{-2}\right)$, as compared to the one in the monoculture (380 plants $\mathrm{m}^{-2}$ ) and also compared to those in the two maize crop systems (518 and 606 plants $\mathrm{m}^{2}$, in monoculture and strips, respectively).

The PRE strategy leveled down all differences caused by crops or crop systems along crop growth and development. The recorded averaged weed density was 117 plants $\mathrm{m}^{2}$.

In the POST strategy, weed densities were not yet influenced by the herbicide at $\mathrm{S} 1$, thus they resemble those in TEST plots. At S2, weed densities ranged from 40 to 80 plants $\mathrm{m}^{-2}$, but no significant difference among crops or crop systems were detected. At S3, the lowest significant weed density was recorded in strip soybeans (30 plants $\left.\mathrm{m}^{2}\right)$, which again did not differ from the one in soybeans in monoculture or in the two maize systems. This trend was almost maintained at S4 and S5 sample times.

Table 3 - ANOVA for weed densities at five sampling times $(\mathrm{S} 1, \ldots \mathrm{Sn})$ of soybeans and maize in strip-intercropping and monoculture under two herbicide strategies (see Table 1), during $\mathrm{Y} 1, \mathrm{Y} 2$ and $\mathrm{Y} 3$

\begin{tabular}{|l|r|c|c|}
\hline \multicolumn{1}{|c|}{ Source } & \multicolumn{1}{c|}{ Df } & $F$ ratio & P \\
\hline Sampling dates & 4 & 4.29 & $0.0053^{* *}$ \\
\hline Years & 2 & 96.04 & $0.0000^{* *}$ \\
\hline Treatments & 11 & 45.88 & $0.0000^{* *}$ \\
\hline Sampling dates x Years & 8 & 7.70 & $0.0000^{* *}$ \\
\hline Sampling dates x Treatments & 44 & 3.62 & $0.0000^{* *}$ \\
\hline Years x Treatment s & 22 & 4.02 & $0.0000^{* *}$ \\
\hline Residual & 498 & & \\
\hline
\end{tabular}


Table 4 - Weed densities in each sample date $(\mathrm{S} 1, \ldots \mathrm{Sn})$ in soybeans and maize in monocultures and strip-intercropping, under two herbicide strategies. Data averaged for Y1, Y2 and Y3. Least significance difference test (LSD) at $\mathrm{p}<0.01$

\begin{tabular}{|c|c|c|c|c|c|}
\hline \multirow{3}{*}{ Treat code } & \multicolumn{5}{|c|}{ Sample times } \\
\hline & S1 & $\mathrm{S} 2$ & S3 & S4 & S5 \\
\hline & \multicolumn{5}{|c|}{ Total weed density $\left(\mathrm{m}^{2}\right)$} \\
\hline SOYMC TEST & $139 \mathrm{ABC}$ & $231 \mathrm{~B}$ & $392 \mathrm{CD}$ & $272 \mathrm{E}$ & $380 \mathrm{~F}$ \\
\hline SOYMC+IMZ & $103 \mathrm{AB}$ & $112 \mathrm{~A}$ & $118 \mathrm{~A}$ & $138 \mathrm{D}$ & $150 \mathrm{CDE}$ \\
\hline SOYMC+GLF & $104 \mathrm{AB}$ & $43 \mathrm{~A}$ & $52 \mathrm{~A}$ & $49 \mathrm{AB}$ & $48 \mathrm{~A}$ \\
\hline SOYSTP TEST & $74 \mathrm{~A}$ & $202 \mathrm{~B}$ & $265 \mathrm{BC}$ & $245 \mathrm{E}$ & $294 \mathrm{E}$ \\
\hline SOYSTP+IMZ & $89 \mathrm{~A}$ & $105 \mathrm{~A}$ & $111 \mathrm{~A}$ & $98 \mathrm{ABCD}$ & $138 \mathrm{BCD}$ \\
\hline SOYSTP+GLF & $112 \mathrm{ABC}$ & $36 \mathrm{~A}$ & $30 \mathrm{~A}$ & $38 \mathrm{~A}$ & $38 \mathrm{~A}$ \\
\hline MZEMC TEST & $327 \mathrm{D}$ & $412 \mathrm{C}$ & $413 \mathrm{D}$ & $373 \mathrm{~F}$ & $518 \mathrm{G}$ \\
\hline ZEMC+ATZ & $101 \mathrm{AB}$ & $101 \mathrm{~A}$ & $124 \mathrm{AB}$ & $108 \mathrm{BCD}$ & $156 \mathrm{CD}$ \\
\hline MZEMC+GLF & $165 \mathrm{ABC}$ & $81 \mathrm{~A}$ & $67 \mathrm{~A}$ & $68 \mathrm{ABC}$ & $73 \mathrm{ABCD}$ \\
\hline MZESTP TEST & $195 \mathrm{BC}$ & $234 \mathrm{~B}$ & $416 \mathrm{D}$ & $277 \mathrm{E}$ & $606 \mathrm{H}$ \\
\hline MZESTP+ATZ & $91 \mathrm{~A}$ & $99 \mathrm{~A}$ & $123 \mathrm{AB}$ & $112 \mathrm{CD}$ & $156 \mathrm{D}$ \\
\hline MZESTP+GLF & $213 \mathrm{C}$ & $79 \mathrm{~A}$ & $66 \mathrm{AB}$ & $67 \mathrm{ABC}$ & $73 \mathrm{AB}$ \\
\hline
\end{tabular}

It is also important to point out increasing densities of an unexpected actor (=volunteer RR maize) in all treatments by Y3 (Figura 2).

\section{Herbicide performance}

Herbicide performance, calculated on the basis of three-year averaged weed seedling densities, reached $73 \%$ efficacy at S2, but no statistical differences were found among crops, crop systems or herbicide strategies. At S5, efficacy of PRE significantly dropped to $66 \%$,

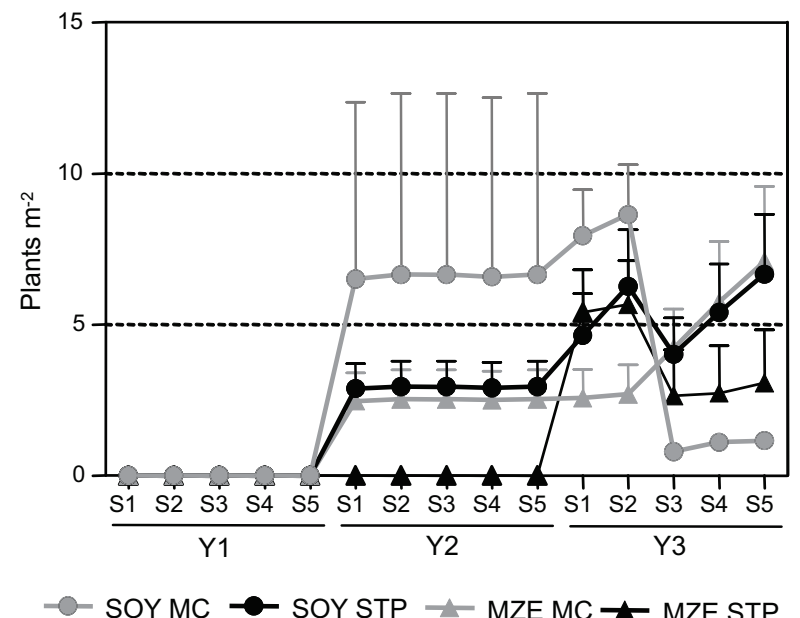

Figure 2 -Volunteer RR maize density (mean plants $\mathrm{m}^{-2}+/-\mathrm{SD}$ ) in TEST. although POST maintained significantly higher control $(87 \%)$ but again no statistical difference was found among crops or crop systems (analysis not shown).

\section{Weed population trajectories}

For the results presented in the previous sections, the three-year averaged weed densities, recorded at the selected sample times, were taken into consideration. However, the calculation of the rate or trajectory for the overall weed community and for each species offers a closer insight into the changes that occurred along the time-course of the experiment (Table 5).

Density of annual monocotyledonous and perennials increased in all TEST treatments $(\lambda>1)$, but density of annual dycotiledoneous was nearly 1 and not influenced by crop or crop systems. No difference was found in $\lambda$ of weed groups in any crop or crop system in the PRE strategy. Differences were found, however, with the POST strategy in annual monocotyledonous: the lowest $\lambda$ occurred in the maize monoculture as compared to maize strip and to the one in the two soybean crop systems.

As far as the particular species are concerned, a significant increase was observed 
of $D$. sanguinalis, E. indica, D. ferox and $S$. halepense, as well as a significant decrease of $P$. oleracea in soybeans strips and a significant increase of $C$. rotundus in monoculture soybeans, in the POST strategy. No significant changes were observed for E. colonum, A. quitensis and Ch. album.

\section{Weed population dynamics and herbicide efficacy}

It has already been demonstrated that strip intercropping significantly reduces the occurrence of weeds, such as in maize (Carruthers, 1998) and beans (Phaseolus vulgaris, (Glowacka, 2010). Our results confirm this trend, because weed populations are significantly reduced by harvest time when both soybeans and maize are cultivated in strips, but a significant reduction was also observed in weed density along crops growth and development, mainly at crop critical periods.

As regards the particular effects of the companion crop on selected species, Leblanc et al. (2002) argued that the presence of crop such as maize did not affect either the emergence patterns of Ch. album and E. crus-galli or their total weed seedling emergence density. They argued that maize canopy may have not developed enough to affect the light levels or soil temperature required for weed germination and, consequently, affect seedling emergence. Also, they suggested extending this situation to other crops grown with wide row spacing and relatively slow canopy closure similar to those of maize: this may be the reason why we did not find density variation in the above-mentioned species. In our experiment, however, not only the dynamics of seedling population but also final weed density were affected by crops and crop systems, , since by crop harvests significant increases in weed densities occured in maize, in both crop systems $\left(517 / 606\right.$ plants $\left.\mathrm{m}^{2}\right)$. Conversely, weed density under soybean crop systems were significantly reduced (380/ 294 seedlings $\mathrm{m}^{2}$ ). One possible explanation about this difference may be searching by inferring the irradiance on the soil surface from data of a complementary experiment under submission- made in the same site and the same seasons: under soybeans canopy, an 
average $26 \%$ reduction in irradiance was measured from V12 to R5 as compared to in the one for maize; Huarte et al. (2003) found that the change in the temperature regime and the red-far red ratio of radiation to which seeds in the soil surface are exposed under alfalfa (Medicago sativa) canopy, reduced weed emergence in those species which require such stimulus to overcome dormancy. The increased build up of weed seedlings in maize may also be associated with an increased replenishment of seeds, since as determined by Davis (2008), at least for $D$. sanguinalis, $C h$. album and $A$. quitensis, only a small proportion of newly produced seeds are recovered by the combine harvester: must of seeds are shed before crop harvest.

Both herbicide strategies leveled differences observed in weed densities along crop cycles, since no difference was observed among crops or crop systems. PRE or POST herbicide strategies achieved 73\% efficacy during the critical period in both crops, and no statistical differences were found among crops, crop systems or herbicide strategies. By the time of crop harvests, weed densities of 140 plants $\mathrm{m}^{-2}$ with PRE strategy ( $66 \%$ control), significantly dropped to 50 seedlings $\mathrm{m}^{2}$ with POST strategy ( $87 \%$ control). Herbicides used in both strategies have been tested for a long time and they are known to provide levels of weed control ranging from acceptable to very good, at least during the critical period in both crops (Hartzler et al., 2006). Such results corroborate the findings by Westra et al. (2008), who found that all treatments which included glyphosate provided significantly better grass control than the non-glyphosate conventional treatments.

A major increase of volunteer maize density occurred in $\mathrm{Y} 3$, as a result of uncollected maize stalks during Y2 harvest whose seeds remained viable in the soil surface until the next season: this "set aside" effect of RR crops is an issue recently reviewed by Boerboom (2009), but it is beyond the scope of this paper.

\section{Diversity}

Weed diversity $\left(H^{\prime}\right)$ was not affected by either crop or crop system. On the contrary, both herbicide strategies, but mainly POST, either in soybeans as monoculture or in maize-strips, significantly increased diversity (Table 6).

Palmer \& Maurer (1997) postulated that although the response depended on the crop type, weed species richness was higher in a multi-intercrop system than in monocultures. Also in natural temperate grasslands, Rodriguez \& Jacobo (2010) found that latesummer applications of glyphosate with the aim to promote the growth of cool season annual grasses caused a shift in the floristic composition, resulting in less rich and even assemblages, dominated by an annual species and impoverishment in native and perennial species. In our experiment, species richness and weed community diversity $\left(H^{\prime}\right)$ were not affected by either crop or crop system. However, the POST strategy either in soybeans as monoculture or in maize-strips significantly enhanced weed community diversity. Results are in line with the findings by Smith $\&$ Gross (2007), who found that the effects of annual crop diversity on weed communities were dependent on the crop rotation phase, and across all phases of rotation, weed community structure was affected more by crop identity than crop diversity per se. After releves made in experiments planted along a transect in the US corn belt, Scursoni et al., (2006) also suggest that higher weed diversity can be maintained with the use of a single application

Table $6-H^{\prime}$ (at S5, Y3). Identical letters indicates that the average is not significant at $\mathrm{p}<0.05$ according to the LSD Test

\begin{tabular}{|c|l|l|}
\hline $\begin{array}{c}\text { Treatment } \\
\mathrm{n}^{\underline{0}}\end{array}$ & Treatment codes & $\mathrm{H}^{\prime}$ \\
\hline 1 & SOYMC TEST & $1.70 \mathrm{BCD}$ \\
\hline 2 & SOYMC+IMZ & $1.73 \mathrm{BCD}$ \\
\hline 3 & SOYMC+GLF & $2.08 \mathrm{E}$ \\
\hline 4 & SOYSTP TEST & $1.52 \mathrm{AB}$ \\
\hline 5 & SOYSTP+IMZ & $1.62 \mathrm{BC}$ \\
\hline 6 & SOYSTP+GLF & $1.77 \mathrm{CD}$ \\
\hline 7 & MZEMC TEST & $1.60 \mathrm{ABC}$ \\
\hline 8 & MZEMC+ATZ & $1.74 \mathrm{CD}$ \\
\hline 9 & MZEMC+GLF & $1.76 \mathrm{CD}$ \\
\hline 10 & MZESTP TEST & $1.59 \mathrm{ABC}$ \\
\hline 11 & MZESTP+ATZ & $1.39 \mathrm{~A}$ \\
\hline 12 & MZESTP+GLF & $1.86 \mathrm{DE}$ \\
\hline
\end{tabular}


or even two application per year of glyphosate, because this strategy allows more weed escapes as compared to non-RR crop systems.

\section{Crop yields and LER}

Since the effect of the years was statistically significant (Table 7), the effects of the treatments on crop yields were analyzed year by year (Figure 3A, B and C). There were not significant yield differences among soybean crop systems or herbicide strategies during Y1, Y2 and Y3. For maize, however, yields in the strip system, whether with POST (Y1) or PREE (Y2 and Y3) strategies, were significantly higher than all other maize treatments.

In the three seasons, LER was significantly higher than 1 in the strip-crops as compared to that in the monocultures in TEST (Table 8). Herbicides strategies enhanced this response in the strip crops, although LER under PRE strategy significant differed from that in monoculture in $\mathrm{Y} 2$ and $\mathrm{Y} 3$ and to that under POST only during Y1.

Table 7- ANOVA for crop yields

\begin{tabular}{|l|r|r|l|}
\hline \multicolumn{1}{|c|}{ Source } & Df & $F$ ratio & \multicolumn{1}{c|}{ P } \\
\hline Treatments & 11 & 190.4 & $0.0000^{* *}$ \\
\hline Year & 2 & 16.2 & $0.0000^{* *}$ \\
\hline Treatments x Year & 22 & 0.59 & $0.92^{\mathrm{NS}}$ \\
\hline Residuals & 105 & & \\
\hline
\end{tabular}

Only maize yields increased in the strip system, and this response was significantly improved by the PRE strategy. The increased response of maize yield in the strip crop is due to an increased solar interception by plants in border rows (Keating \& Carberry, 1993). On the contrary, in soybeans POST strategy in monocultures significantly outyielded PRE and TEST in both crop systems, which did not differ. Thus, LER was significantly higher than 1 in the strip-crops as compared to the monocultures in the TEST, in the three seasons. LER values were higher than those reported by Dariush et al. (2006) for maize variety intercropping (LER=1.06). As previously mentioned, herbicide strategies enhanced this response in variable ways: LER with PRE strategy differed significantly from the one in the monoculture in $\mathrm{Y} 2$ and $\mathrm{Y} 3$, but it differed from the POST strategy only during Y1: rainfall pattern and water availability within maize critical period may account for the differences.
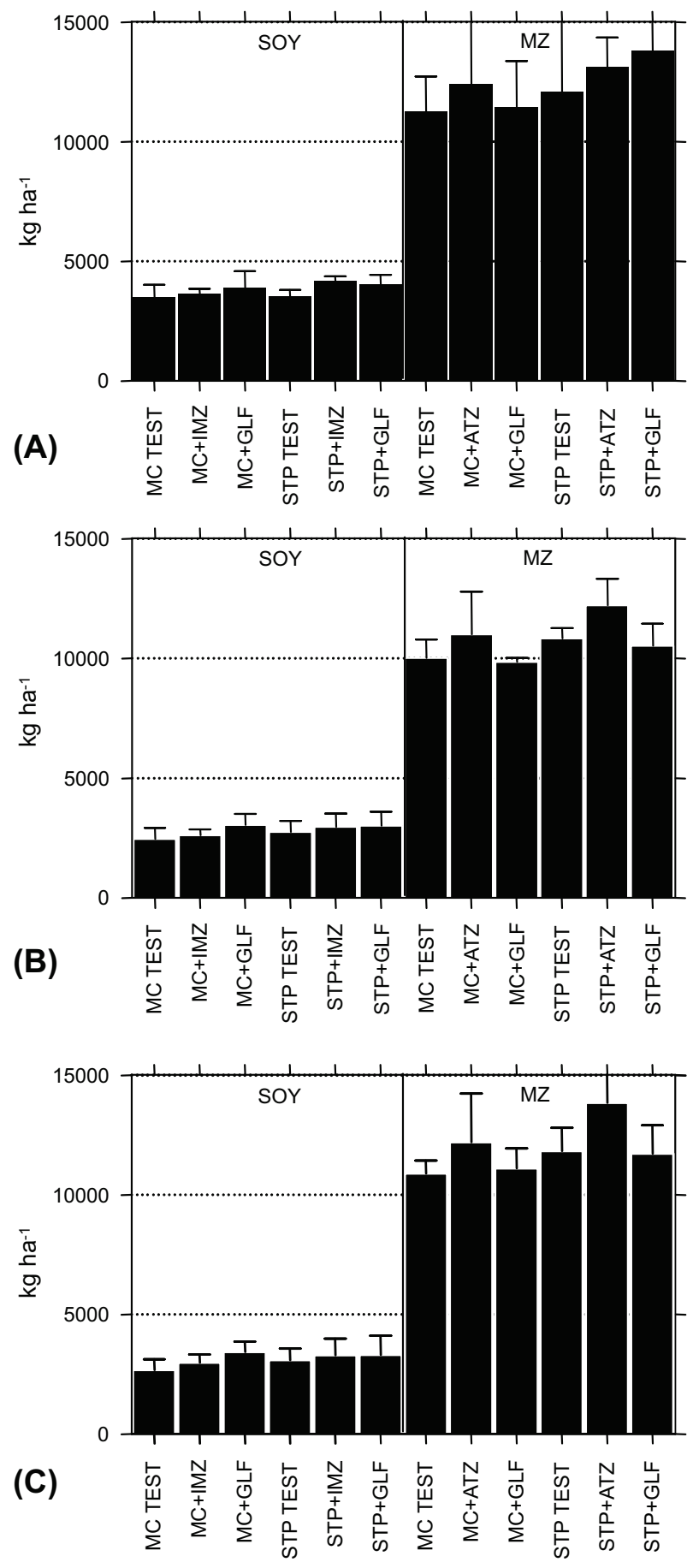

Figure 3 - (A) Crop yields (mean yields +/- SD) in Y1; (B) Crop yields (mean yields $+/-\mathrm{SD}$ ) in Y2. (C) Crop yields (mean yields +/- SD) in Y3. 


\section{Herbicide environmental loads (HELs)}

The highest HELs were calculated for soybeans either in monoculture or in strips + POST (treatments $\mathrm{n}$ - 3 and 6, respectively), and also for all maize treatments (treatments no 8, 9, 11 and 12). The calculated HEL was somewhat lower in soybean strips + PRE (treatment $\mathrm{n}$ o 5), but the lowest HEL was observed in soybean monoculture + PRE (treatment no 2) (Table 9). The environmental load of all herbicide treatments fall in very low (treatment $\mathrm{n}^{\circ} 2$ ) or low EIQ field use ratings (treatments $\mathrm{n}-3,5,6,8,9,11$ and 12), according to a Table recommended to rate the chemicals used in turfgrass (IPM guidelines: http:/ /ipmguidelines.org/Turfgrass/content/ CH01/default-13.asp.)

Table 8 - LER (LSD at $\mathrm{p}<0.05)$

\begin{tabular}{|l|c|c|c|}
\hline & Y1 & Y2 & Y3 \\
\hline Monoculture & $1.00 \mathrm{~A}$ & $1.00 \mathrm{~A}$ & $1.00 \mathrm{~A}$ \\
\hline Strip-TEST & $1.06 \mathrm{~B}$ & $1.09 \mathrm{~B}$ & $1.10 \mathrm{~B}$ \\
\hline Strip-PRE & $1.03 \mathrm{~A}$ & $1.12 \mathrm{~B}$ & $1.13 \mathrm{~B}$ \\
\hline Strip-POST & $1.16 \mathrm{C}$ & $1.05 \mathrm{AB}$ & $1.03 \mathrm{~A}$ \\
\hline
\end{tabular}

Table 9 - HELs

\begin{tabular}{|c|c|c|}
\hline Treatment $\mathrm{n}^{\mathbf{0}}$ & Treatment codes & HEL's \\
\hline 1 & SOYMC TEST & 0 \\
\hline 2 & SOYMC+IMZ & 10.08 \\
\hline 3 & SOYMC+GLF & 35.28 \\
\hline 4 & SOYSTP TEST & 0 \\
\hline 5 & SOYSTP+IMZ & 26.95 \\
\hline 6 & SOYSTP+GLF & 35.28 \\
\hline 7 & MZEMC TEST & 0 \\
\hline 8 & MZEMC+ATZ & 35.28 \\
\hline 9 & MZEMC+GLF & 32.28 \\
\hline 10 & MZESTP TEST & 0 \\
\hline 11 & MZESTP+ATZ & 35.28 \\
\hline 12 & MZESTP+GLF & 35.28 \\
\hline
\end{tabular}

Not only crops but also crop systems differentially influenced weed densities along their growth and development. By crops harvests, significant weed density increases were observed in both maize crops systems as compared to those in soybeans, with the lowest one being observed in soybean strips.

Differences were levelled by both herbicide strategies, which achieved $73 \%$ efficacy during the critical periods in both crops. For crop harvests however, PRE efficacy dropped significantly when compared to POST efficacy. The trajectory of annual monocotyledonous (grasses) showed an increase $(\lambda>1)$ along the three-year experiment (the least in maize monoculture + POST), thus shifting weed community composition.

Species richness and $H^{\prime}$ were not affected by crops or crop systems. Both herbicides strategies particularly POST, either in soybeans in monoculture or maize strips, significantly enhanced weed community diversity.

Crops yields significantly increased in the strip system, but only in maize when coupled with herbicides, either POST (Y1) or PRE (Y2, Y3) strategies. LER was significantly higher than 1 in the strip-crop systems over the three years. Herbicides enhanced this response, although the effects of each strategy varied according to the season. Although the lowest HEL was found in soybean monoculture + PRE strategy, all herbicide strategies in both crops and systems fall within Low Use in a rating system created to monitor EIQ in turfgrass.

\section{ACKNOWLEDGEMENTS}

The support of the farm owner, Mr G. Verdelli and the expertise of advanced pupils of "Colegio Agrotécnico ITAI" for weed sampling is greatfully acknowledged. The experiment is part of CONICET / UNR AG 128 ESL Project and also of DV Ph D Thesis.

\section{LITERATURE CITED}

ACCIARESI, H.; SARANDON, S. J. Manejo de malezas en una agricultura sustentable. In: SARANDON, S. J. (Ed.).

Agroecología: el camino hacia una agricultura sustentable. La Plata: Ediciones Científicas Americanas, 2001.

BEDMAR, F.; MANETTI, P.; MONTERUBBIANESI, G. Determination of the critical period of weed control in corn using thermal basis. Pesq. Agropec. Bras., v. 34, n. 2, p. 187-193, 1999. 
BOERBOOM, C. Volunteer RR corn: A new soybean weed? $2009<\mathrm{http}: / /$ ipcm.wisc.edu>. Accessed: 20 Feb. 2011.

BROOKES, G.; BARFOOT, P. GM crops: global socioeconomic and environmental impacts 1996-2006. Dorchester: PG Economics, 2008.

CARRUTHERS, K. et al. Intercropping corn with soybean, lupin and forages: yield component responses. Europ. J. Agron., v. 12, n. 2, p.103-115, 2000.

COUSENS, R.; MORTIMER, M. Dynamics of weed populations. Cambridge: University Press, 1995. 334 p.

CULPEPPER, S. A. Glyphosate-induced weed shifts. Weed Technol., v. 20, p. 277-281. 2006.

DARIUSH, M.; AHAD, M.; MEYSAM, O. Assessing the land equivalent ratio (LER) of two corn (Zea mays L.) varieties intercropping at various nitrogen levels in Karaj, Iran. J. Central Europ. Agric., v. 7, n. 2, p. 359-364, 2006.

DAVIS, A. Weed seed pools concurrent with corn and soybean harvest in Illinois. Weed Sci., v. 56, n. 4, p. 503-508, 2008.

EYHERABIDE, J. J.; CENDOYA, M. G. Critical periods of weed control in soybean for full field and in furrow interference. Weed Sci., v. 50, n. 2, p. 162-166, 2002.

FEHR, W. R.; CAVINESS, C. E. Stages of soybean development. Ames: Iowa State University, 1977. (Experimental. Station Special Report, 80)

GLOWACKA, A. Changes in weed infestation of common bean (Phaseolus vulgaris L.) under conditions of strip intercropping and different weed control methods. Acta Agrobot., v. 63, n. 2, p. 171-178, 2010.

HALL, M. R.; SWANTON, C. J.; ANDERSON, G. M. The critical period of weed control in grain corn (Zea mays L.). Weed Sci., v. 40, n. 4, p. 441-447, 1992.

HARTZLER, R. G.; SINGER, J. W.; OHLER, K. A. Effect of repeated glyphosate use on weed communities in a soybeancorn rotation. Plant management network. 2006. Disponible em: <http://www.plantmanagementnetwork.org/ pub/cm/research/2006/weed/>. Accessed: 12 Feb., 2011.

HUARTE, R.; BENECH ARNOLD, R. Understanding mechanisms of reduced annual weed emergence in alfalfa. Weed Sci., v. 51, p. 876-885, 2003.

IMP Guideliness: <http://ipmguidelines.org/Turfgrass/ content/CH01/default-13.asp>. Accessed: 10 Feb., 2011.
KEATING, B. A.; CARBERRY, P. S. Resource capture and use in intercropping: solar radiation. Field Crops Res., v. 34, n. 3-4, p. 273-301, 1993.

KOVACH, J. et al. A method to measure the environmental impact of pesticides. New York Food Life Sci. B., v. 9, n. 1, p. 1-9, 1992.

LEBLANC, M. L. et al. Effect of the presence or absence of corn on Common Lambsquarters (Chenopodium album.L.) and Barnyardgrass (Echinochloa crus-galli L. Beauv.) emergence. Weed Technol., v. 16, n. 3, p. 638-644, 2002.

LEGUIZAMÓN, E. S. Transgenic crops in Argentina: present status and implications. 2001. AgBiotechnet. $<$ http:/ /www.agbiotechnet.com/Reviews.asp>. Accessed: 10 Oct. 2010.

LESOING, G.; FRANCIS, C. Strip intercropping effects on yield and yield components of corn, grain sorghum, and soybean. Agron. J., v. 91, p. 807-813, 1999.

POWLES, S. B. Evolved glyphosate-resistant weeds around the world: lessons to be learnt. Pest Manag. Sci., v. 64, n. 4, p. $360-365,2008$.

LIEBMAN, M.; DYCK, E. Crop rotation and intercropping strategies for weed management. Ecol. Appl., v. 3, n. 1, p. 92-122, 1993.

MEAD, R.; WILLEY, R. D. The concept of a 'Land Equivalent Ratio' and advantages in yields from intercropping. Exper. Agric., v. 16, n. 2, p. 217-228, 1980.

OWEN, M. D. K.; ZELAYA, I. A. Herbicide-resistant crops and weed resistance to herbicides. Pest Manag. Sci., v. 61, n. 4, p. 301-311, 2005 .

PALMER, M. W.; MAURER, T. A Does diversity beget diversity? A case of study of crops and weeds. J. Veget. Sci., v. 8, n. 2, p. 235-240, 1997.

RITCHIE, S.W.; HANWAY, J. J. How a corn plant develops. Ames: Cooperative Extension Service, 1982. p. 1-4. (Special Report, 48)

RODRIGUEZ, A.; JACOBO, E. Glyphosate effects on floristic composition and species diversity in the flooding pampa grassland (Argentina). Agric. Ecosyst. Environ., v. 138, n. 2, p. 222-231, 2010.

SARANDON, S. J.; CHAMORRO, A. M. Policultivos en los sistemas de producción de granos. In: SATORRE, E. H. (Ed.). Producción de granos: bases funcionales para su manejo. Buenos Aires: Facultad de Agronomía, 2004. p. 481-500. 
SCURSONI, J.; FORCELLA, F.; GUNSOLUS, J. Weed diversity and soybean yield with glyphosate management along a north-south transect in the United States. Weed Sci., v. 54, n. 4 , p. $713-719,2006$

SMITH, R. G.; GROSS, K. L. Assembly of weed communities along a crop diversity gradient. J. Appl. Ecol., v. 44, n. 4, p. 1046-1056, 2007.
VITTA, J.; TUESCA, D.; PURICELLI, E. Widespread use of glyphosate tolerant soybean and weed community richness in Argentina. Agric. Ecosyst. Environ., v. 103, n. 5, p. 621-624, 2004.

WESTRA, P. H. et al. Weed population dynamics after six years under glyphosate and conventional herbicide-based weed control strategies. Crop Sci., v. 48, n. 3, p. 1170-1177, 2008. 